\title{
Tarkwa Gold Mine, Ghana, West Africa - A Case Example of Upgrading the Reliability of Reserves by Improved Accounting for Structural Geology in Pit Designs
}

\author{
G.B. Avane Gold Fields of Ghana Ltd, West Africa \\ A.F. Saayman Xamine Consulting Services, Australia
}

\begin{abstract}
Structural geologic controls play major roles in the genesis and physical characteristics of Tarkwaian gold deposits in the Ashanti gold belt in Ghana. The Ashanti belt is a member of the extensively researched Eburnean orogenic event that metamorphosed, deformed, faulted and fractured the Birimian Super Group and the Tarkwaian Group rocks. This tectonic history determined the ultimate spatial distribution, size, geometry, physical characteristics and virgin stress regimes of the gold deposits exploited at Tarkwa Gold Mine.

Structural geological controls are well understood and extensively used in exploration. Regrettably, geotechnical investigations often do not award due attention to structural geologic settings of deposits and to modelling major geologic structures, in order to identify and analyse potential failure mechanisms. This paper discusses redesign of the "Midlap \& Underlap" pit as case example of structural oversight. Slope designs of the Tarkwa pits were based on the empirical Mining Rock Mass Ratings (MRMR) method, classical stereographic analysis, limit equilibrium analyses and numerical modelling using FLAC. Major structures were not explored and modelled in detail, consequently were inadequately accounted for in pit designs. Slope instability early in pit development and geotechnical reviews indicated high probability for major slope failures, in particular untenable risks of losing key ramps if the original mine plans were followed. Pit redesign and consequential changes to ore reserves emphasized the importance of basing geotechnical designs on methodical structural geologic modelling from the earliest studies. Ore reserve classifications should reflect the reliability of geotechnical models and resulting pit designs.
\end{abstract}

\section{Tarkwa Gold Mine}

The Tarkwa mine is located in south-western Ghana, approximately $300 \mathrm{~km}$ west of the capital Accra, at latitude $5^{\circ} 15^{\prime} \mathrm{N}$ and $2^{\circ} 00^{\prime} \mathrm{W}$ (see Figure 1). Access is by a tarred road and rail which also connect the mine to the port of Takoradi, approximately $60 \mathrm{~km}$ to the south-east. Grififis et al. (2002).

Mining in the Tarkwa area can be traced back to the early 19th century, with production continuing intermittently to this day. Gold Fields Ghana Limited took control of the Abontiakoon Vertical Shaft complex from the State Gold Mining Company (SGMC) in 1993. Open pit mining and heap leach operations commenced in 1998 and underground operations were suspended in mid 1999. The Tarkwa Gold Mine currently comprises a large open pit operation utilising a highly selective mining method to produce approximately 700,000 oz of gold per annum by heap leach cyanide extraction and Carbon in Leach (CIL) extraction.

The topography of the mine site is dominated by pronounced ridges which reflect the underlying structural geology. The area is drained by secondary streams towards the west. There are no major rivers located on the mine property. Annual rainfall in the Tarkwa region averages $2030 \mathrm{~mm}$, but annual and seasonal fluctuations are becoming increasingly pronounced. Storm events that deposit more than $70 \mathrm{~mm}$ in an hour are becoming frequent. Structural geologic complexity and extreme rainfall events pose serious challenges to pit design and maintaining depressurised, stable slopes. 


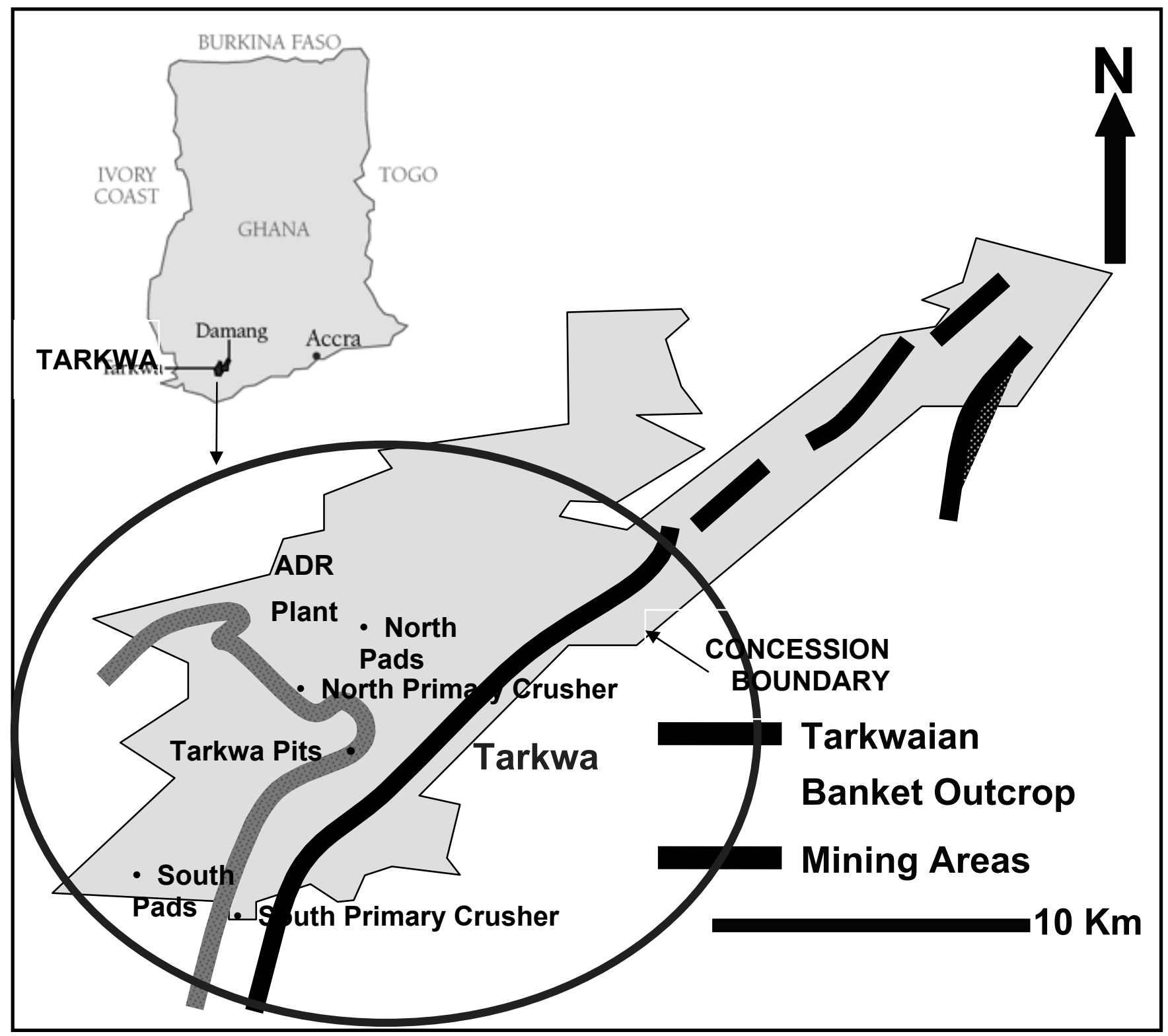

Figure 1 Location map of the Tarkwa Gold Mine in Ghana

\section{Regional geology}

In Ghana, the Birimian greenstone belt sequence occurs as irregular basins of predominantly metasedimentary strata, separated by a series of north-east trending belts of metavolcanics in which most of the gold deposits are clustered on a north-west striking belt, the Ashanti belt (see Figure 2). The Birimian greenstone belts are un-conformably overlain by Proterozoic age Tarkwaian metasediments, which host the gold mineralisation at the Tarkwa mine. This gold mineralisation is concentrated in conglomerate reefs, similar to that of the Witwatersrand system. The Au-deposits at Tarkwa is composed of a succession of flat dipping stacked tabular paleo-placer units, consisting of quartz pebble conglomerates within Tarkwaian sedimentary rocks. Approximately ten such separate economic units occur in the concession area within a sedimentary package that is between 40 and 110 metres thick. Low grade to barren quartzite units are interlayered with the Au-reefs. 


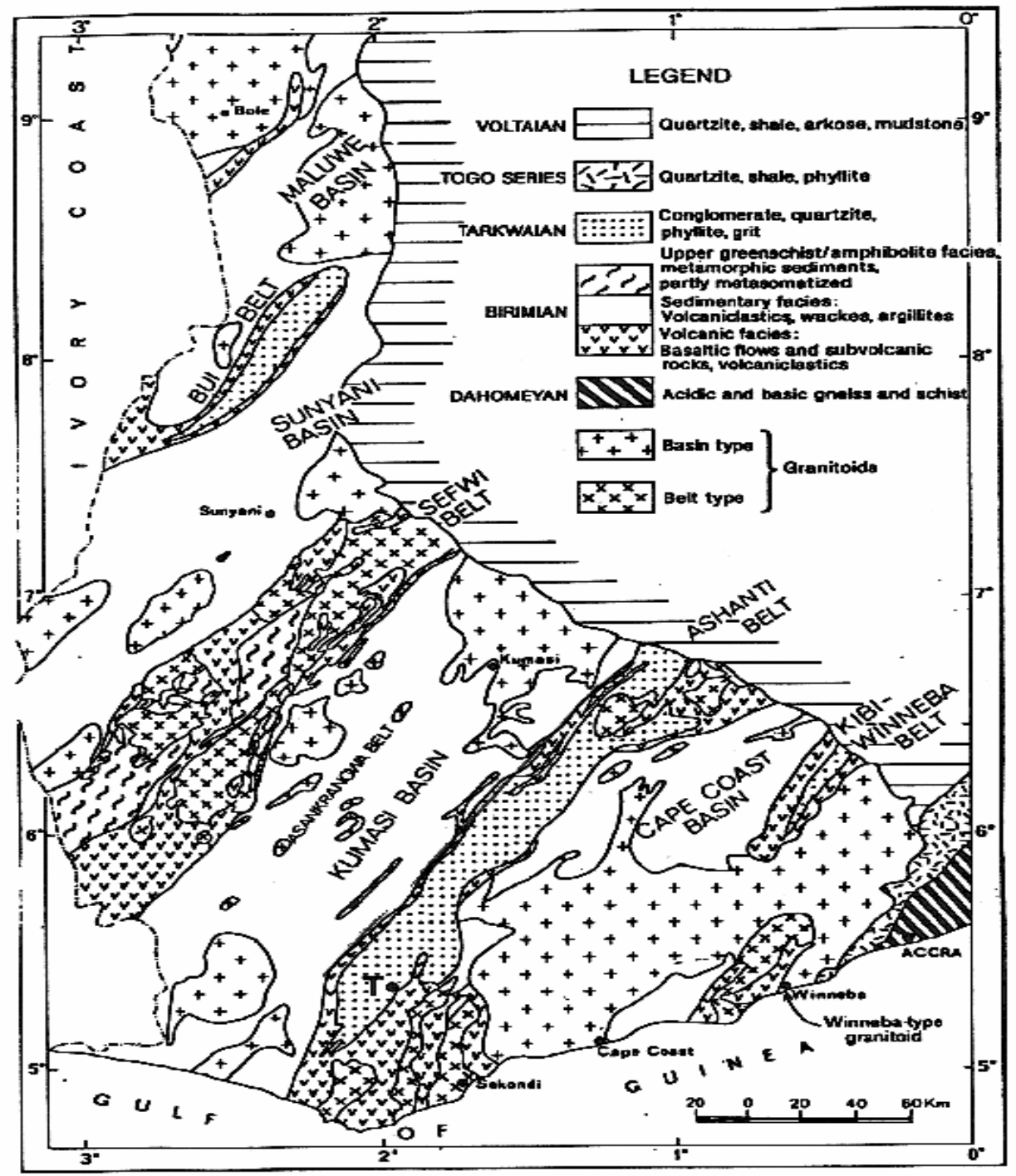

Figure 2 Geology of west and central Ghana and the location of the Tarkwa Concession (T)

\section{Regional structural deformation}

The Ashanti belt is a member of the extensively researched Eburnean orogenic event that metamorphosed, deformed, faulted and fractured the Birimiam Super group and the Tarkwaian Group rocks. Five phases of structural deformation (D0 to D4) have been identified in the Tarkwa region (Karpeta, 2001).

\subsection{D0 deformation}

The D0 event produced the Tarkwa depositional basin as an extensional half-graben. A north-east striking master normal fault (the Prestea lineament) formed the west margin that sourced small alluvial fans. Subsidiary faults and rollovers on the eastern margin sourced extensive fluvial systems that fed sands and gravels into the basin. East-west cross structures (Summang, N1 and Fanti-Abosso break) acted as transfer faults between normal fault segments and compartmentalized the basin as schematically shown in Figure 3.

\subsection{D1 deformation}

The D1 event was prolongation of the D0 event resulting in normal faulting of the basin fills itself. These D1 synthetic and antithetic normal faults acted as buttresses to the D2 compression and were inverted (reactivated as steep reverse faults (see Figure 3). Bedding-plane parallel basic sills also intruded during D1 tectonics. 


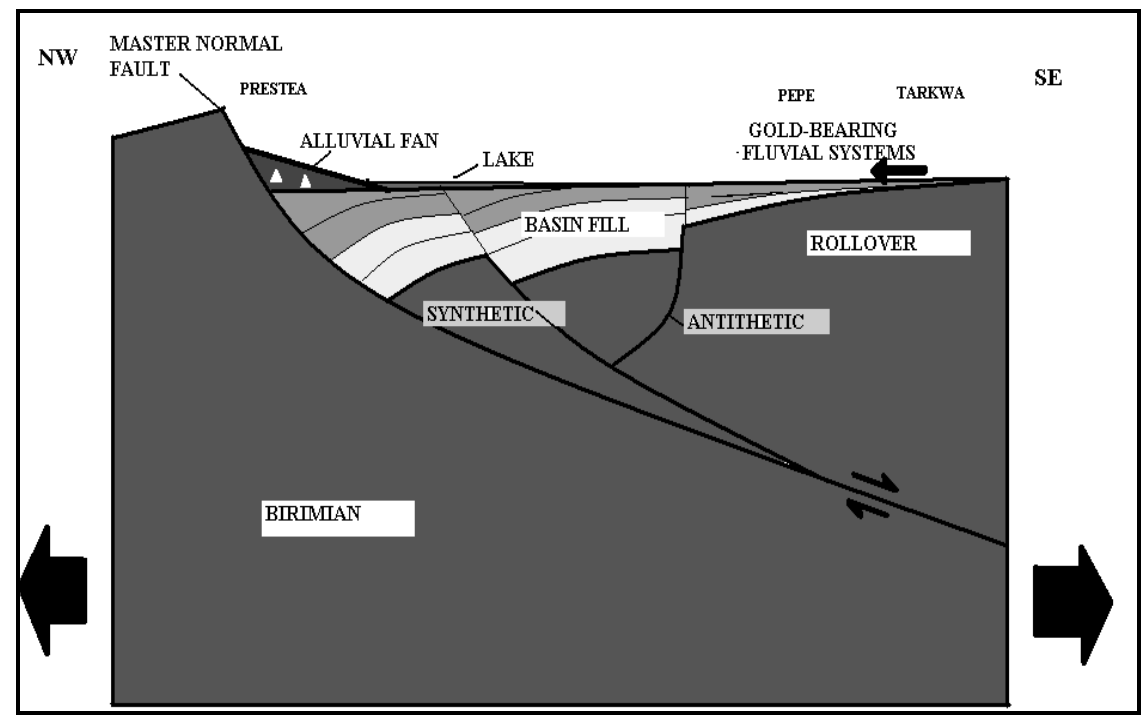

Figure 3 Normal faulting associated with D0/1 extension

\subsection{D2 deformation}

D2 deformation involved NW-SE sub-horizontal compressive stress producing NE striking thrusting and folding. Early D2 deformation was thin-skinned and was concentrated in the basin-fill. It produced NW and SE verging bedding-plane parallel thrusts and back thrusts in the more incompetent horizons like the Footwall quartzite (FW), the B quartzite (B) and the hanging wall (HW) quartzite horizons, which ramped up through the reefs at buttresses, forming imbricate thrusts. Acid sills and dykes intruded along some of these early thrust planes. Major structures in the Midlap and Underlap pit, discussed in following sections, formed during D2 deformation. The Underlap and Overlap faults are examples of imbricate thrusts (see Figure 4).

Subsequent D2 deformation impacted on both the basin fill and the basement rocks, producing thick skinned deformation. Basement deformation resulted in the inversion of the D0/D1 normal faults as steep thrusts and the basin fill was folded into open, cylindrical flexural slip folds. The Tarkwa Syncline and Pepe Anticline are examples of this type of deformation. The final D2 deformation phase caused large, SE verging thrusts, locally named the Kottraverchy and Plateau Thrusts, as well as the Basement decollement. These are interpreted as "out of the graben" thrusting associated with partial expulsion of the basin fill (see Figure 4).

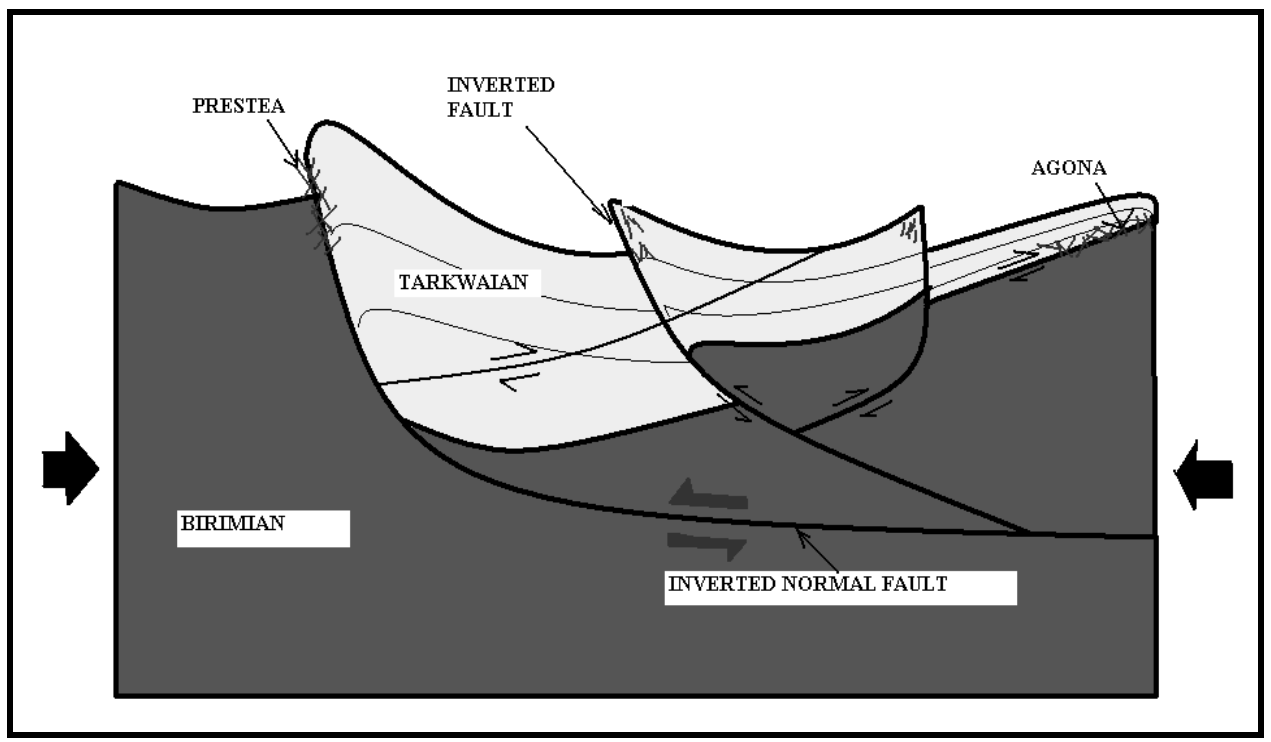

Figure 4 D2-inversion of basin-fill sediments 


\subsection{D3 deformation}

D3 deformation involved a sub vertical, NE-SW oriented sinistral shear couple, which produced strike-slip movement on the basin-margin faults resulting for example in the Prestea Lineament. South to southwest verging thrusts (for example the Muva and Syncline Faults) and minor folds occurred within the basin. The E-W cross structures may have acted as buttresses concentrating thrust ramps around them (see Figure 5).

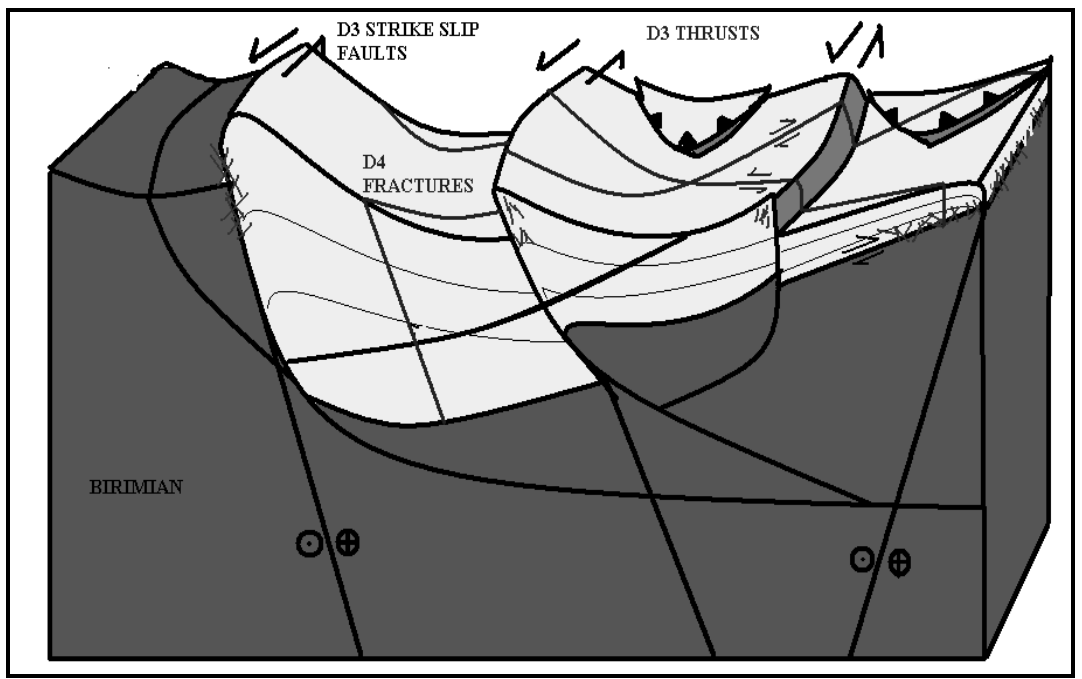

Figure 5 Thrust faulting and folding due to D3/D4 deformation

\subsection{D4 deformation}

The D4 event involved renewed sub horizontal NW-SE compression, which produced sub vertical arrays of WSW and NNW striking conjugate fractures and faults, locally named 'Franks Faults' (see Figure 5). The D4 event also involved the final movement on the cross structures and the intrusion of a basic dyke along the Summang river.

\section{$4 \quad$ Pre-feasibility and phase 2 slope designs}

Pre-feasibility geotechnical investigations and slope design recommendations were originally (in 1996) limited to only the Pepe pit. Phase 2 geotechnical investigations and slope designs aimed to advance designs of several pits of Tarkwa mine beyond pre-feasibility level were launched in 2002. However, geotechnical drill holes were very widely spaced, not ideally located and cores were not oriented. Limited cell or window mapping data were added. Reef identifications and structural interpretations were based on diamond drill holes typically spaced more than $1000 \mathrm{~m}$ apart, and on reverse circulation (RC) drilling typically on $25 \mathrm{~m} \mathrm{x}$ $50 \mathrm{~m}$ grids. The wide data spacing made interpretations in complex structural domains very difficult and unreliable. Structural interpretations were carried out only by resource geologists whose primary focus on major structures was limited to those that displaced gold bearing reefs. To further complicate the geotechnical designs, structural models were restricted to mineralised reefs and did not extent to where pit slopes would likely be constructed, nor to below footwalls. Very little groundwater information was available, apart from inferences made from lakes, swamps and streams on the property. Geomechanical tests have been carried out on only two material samples at that stage, i.e. one from a felsic sill and one from a mafic sill (Haines, 2002).

Table 1 provides a summary of the geotechnical input data collected and applied in the 2 nd phase study. Slope designs were essentially based on the empirical Mining Rock Mass Ratings (MRMR) method, classical stereographic analysis, limit equilibrium analyses and numerical modelling using FLAC®. The strength of saprolite which overlie highly to moderately weathered rock (sap-rock) and fresh rock was determined from only two laboratory shear tests. Estimates of rock mass shear strengths were derived by empirical methods from rock mass classifications done on un-oriented drill core. The potential impacts of weathered, very weak sills on hanging-wall slopes were numerically analysed (with FLAC) applying the same empirically derived rock mass strength as inputs. 
Table 1 Summary of data sources used in pre-feasibility studies (Haines, 2002)

\begin{tabular}{lcccccccc}
\hline Pit & $\begin{array}{c}\text { D-Core } \\
\text { holes } \\
\text { drilled } \\
(2002)\end{array}$ & $\begin{array}{c}\text { No. of DD holes } \\
\text { logged } \\
\text { geotechnically }\end{array}$ & $\begin{array}{c}\text { Spacing } \\
\text { of DD } \\
\text { holes }\end{array}$ & $\begin{array}{c}\text { RC } \\
\text { Drilling } \\
(2002)\end{array}$ & $\begin{array}{c}\text { Spacing } \\
\text { of RC holes }\end{array}$ & $\begin{array}{c}\text { Mapping } \\
\text { Windows }\end{array}$ & $\begin{array}{c}\text { No. } \\
\text { of } \\
\text { Piezos }\end{array}$ \\
\hline Name & No. & $\begin{array}{c}\text { Un- } \\
\text { oriented }\end{array}$ & Oriented & (m) & No. & (m) & No. & No. \\
\hline Pepe-Mantraim & 302 & 9 & 0 & $\geq 1000$ & 5316 & $25 \times 50$ & 7 & 0 \\
Teberebie & 213 & 3 & 0 & $\geq 1000$ & 2032 & $25 \times 50$ & 2 & 0 \\
Kottraverchy & 158 & 2 & 1 & $\geq 1000$ & 221 & $25 \times 50$ & 0 & 0 \\
$\begin{array}{l}\text { Akontansi } \\
\text { Central/Ridge }\end{array}$ & 377 & 4 & 0 & $\geq 1000$ & 2013 & $25 \times 50$ & 0 & 0 \\
$\begin{array}{l}\text { Akontansi East } \\
\text { (Midlap- }\end{array}$ & 200 & 1 & 0 & $\geq 1000$ & 4100 & $25 \times 50$ & 2 & 0 \\
Underlap) & & & & & & & & \\
\hline
\end{tabular}

Structural geologic evaluation was limited to assessing existing 2D sections. Geotechnical studies did not include research of the tectonic setting and major structures were not specifically explored for, nor modelled in 3-D. Some sub-vertical and sub-horizontal thrusts were noted as 'principal structures', and to limit their influence on slope stability it was recommended to limit bench-stacks to $72 \mathrm{~m}$ high at $60^{\circ}$, separated by $15 \mathrm{~m}$ wide berms (Haines, 2002).

Unfortunately, as sometime happens, these preliminary design parameters were also applied in advanced pit designs for feasibility-level and ultimate reserve estimations. Slope instability early in pit development and geotechnical reviews indicated untenable risks of major slope failures and particularly for losing key access ramps, if original mine plans were followed. It became clear that the potential impacts of major structures, i.e. folding, faulting and weathered dykes/sills, were inadequately accounted for in slope designs, pit layouts and development sequencing.

\section{Redesign of the Midlap and Underlap pit}

The Midlap Pit is the starter pit or first phase of the larger Underlap Pit. The pit names refer to imbricate fault blocks of strata between the Overlap and Underlap thrust faults. Figure 6 shows the relative positions and scales of the Tarkwa mine open pits and in particular the location of the Midlap and Underlap pit. The slope design parameters recommended in 2002 for designing the Akontansi East (encompassing the Midlap and Underlap pits/phases) are summarised in Table 2. The original pit designs and ramp layouts based on these specifications are shown in Figure 6.

Table 2 Original Midlap and Underlap pit slope specifications

\begin{tabular}{lcccc}
\hline Pit & Pit Type & Slope Location & $\begin{array}{c}\text { Geology (see } \\
\text { legend below) }\end{array}$ & $\begin{array}{c}\text { Overall Slope } \\
\text { Angle }\end{array}$ \\
\hline \multirow{3}{*}{ Akontansi East } & Oxide & Upper & OB, SR, INT & $45^{\circ}$ \\
\cline { 2 - 5 } & & Lower & OZP & $65^{\circ}$ \\
\cline { 2 - 5 } & \multirow{2}{*}{ CIL } & Upper & OB, SR, INT & $45^{\circ}$ \\
& & Lower & OZP & $60^{\circ}$ \\
\hline
\end{tabular}

$\mathrm{OB} \quad=$ Overburden

SR $\quad=$ Soft Rock $=$ Saprolite

INT = Intermediate zone between Saprolite and Lower Hard/Fresh rock

OZP $\quad=$ Ore Zone Package $=$ Lower Hard Rock 
Infill drilling to upgrade the resource classifications, the 2004-05 mine-wide geotechnical structural geological study, as well as slope instability problems in nearby pits raised a number of geotechnical concerns about the reliability of the Midlap and Underlap designs. Completely weathered (to clay) dykes and sills could be observed in nearby road cuts and in the adjacent West Hill pit. A number of diamond cores holes that extended into the footwall, drilled prior to the 2002 studies intersected these sills. Their geometry and number were however inconclusive. Figure 7 shows a section on which one of these core holes intersected all four sills, but RC-holes drilled to explore only the Midlap reefs stopped short of the deeper sills and also of the interim and ultimate pit footwall slopes. Even these early models indicated that this ramp-slope (west slope) would most likely fail if the original mine plan was followed.

The potential impacts of groundwater on the slopes and operations was also of particular concern, as the regional Midlap and Underlap thrust faults strike through the pit and underneath a large swamp located directly north of the planned pit limit.

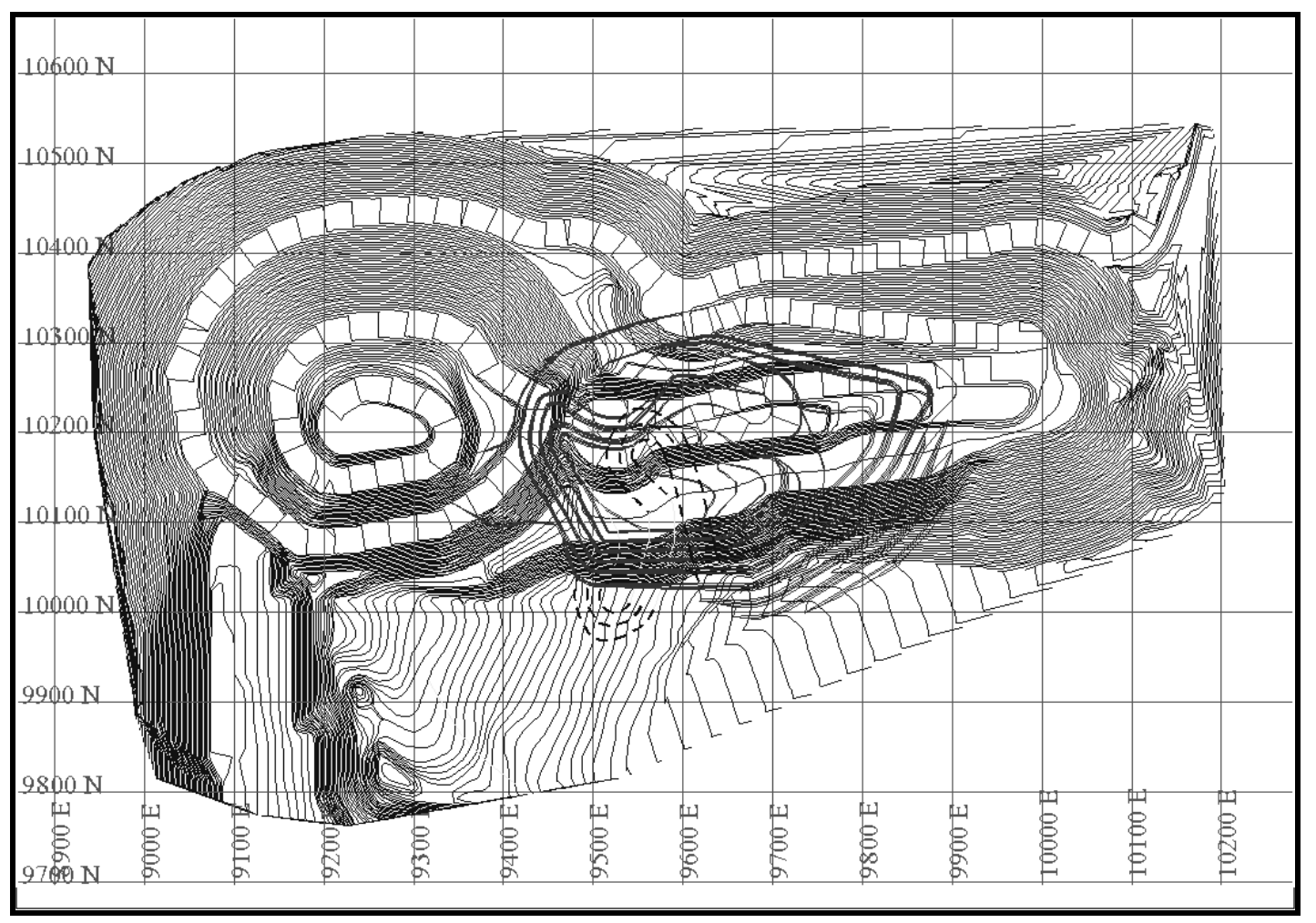

Figure 6 The original small Midlap starter pit inside the large, final Underlap pit

\subsection{Structural geological investigations and modelling}

Tarkwa mine from 2004 embarked on a program of dedicated geotechnical exploration, structural geologic research and modelling of major structures (strata, folding, faulting and intrusives). The primary objectives were to derive inputs for upgrading geotechnical slope designs and the reliability of ore reserves. The spacing of diamond drill (DD) holes was closed from $1000 \mathrm{~m}$ to at least $100 \mathrm{~m}$ all around the mine. The spacing of reverse circulation (RC) holes was generally reduced to $25 \mathrm{~m} \mathrm{x} 25 \mathrm{~m}$, but in the more structurally complex pits the spacing was further reduced to $12.5 \mathrm{~m} \mathrm{x} 12.5$ and $12.5 \mathrm{~m} \mathrm{x} 25 \mathrm{~m}$. All inclined DD holes were oriented, all DD and selected RC holes were drilled $30 \mathrm{~m}$ into footwall and specifically logged for major structures. Groundwater levels are monitored by means of piezometers which are replaced and augmented as these are mined out or access is lost. Table 3 summarises field data sources at the end of 2005.

Unfortunately production pressures did not allow time for additional diamond drilling in the Akontansi East (Midlap and Underlap) pit, but a decision was taken to utilise an ongoing RC exploration program to gain better structural geological information. Intrusives and marker strata can be recognised by logging RC chips. 


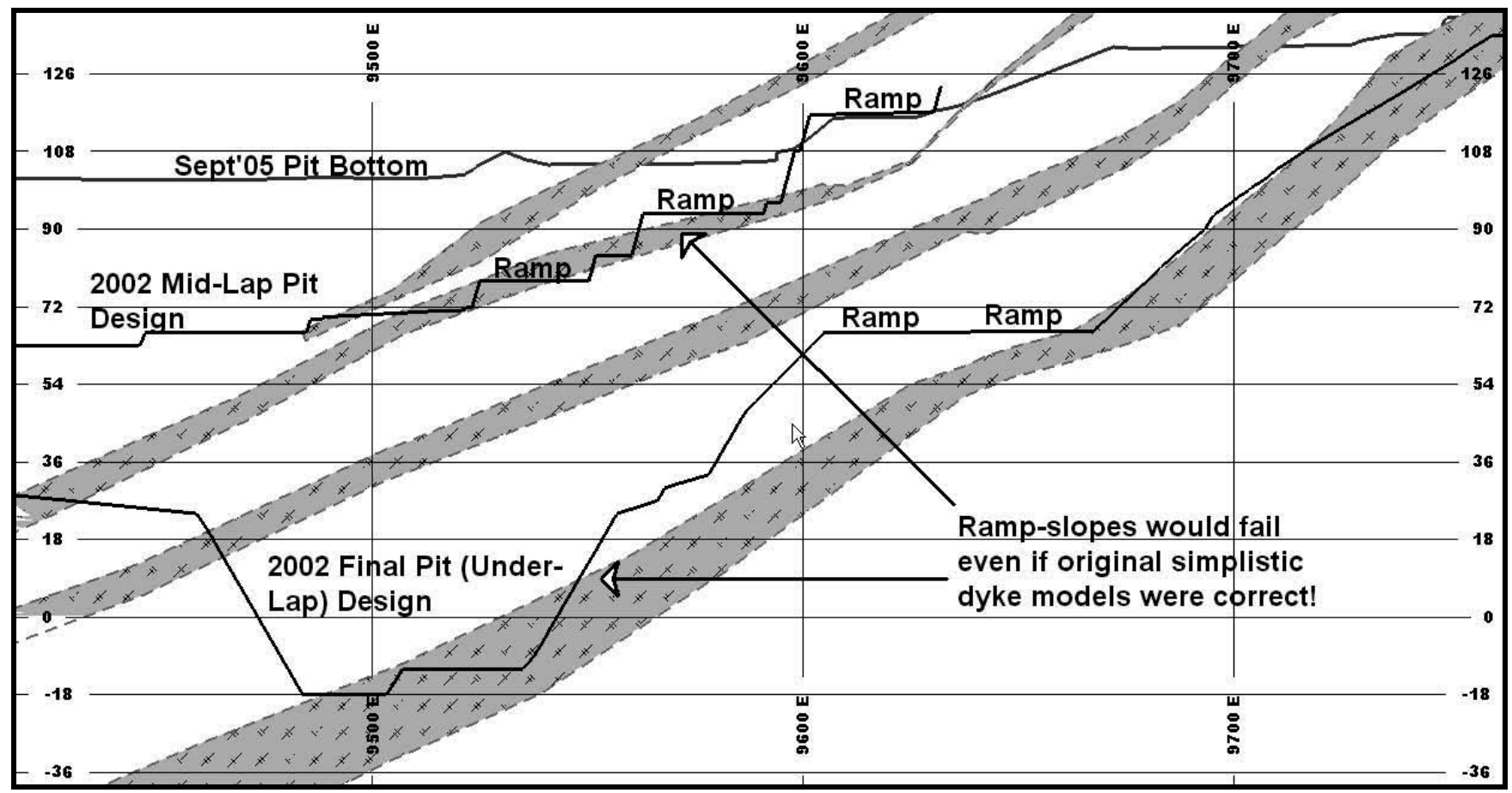

Figure 7 A section through the first Midlap and Underlap pit designs and simplistic models of sills

Table 3 Summary of data used at 1st review of designs (Saayman, 2005)

\begin{tabular}{|c|c|c|c|c|c|c|c|c|}
\hline Pit & $\begin{array}{l}\text { D-Core } \\
\text { holes } \\
\text { drilled } \\
(2005)\end{array}$ & $\begin{array}{r}\text { No. o } \\
1 \\
\text { geote }\end{array}$ & $\begin{array}{l}\text { holes } \\
\text { d } \\
\text { ically }\end{array}$ & $\begin{array}{l}\text { Spacing of } \\
\text { DD holes }\end{array}$ & $\begin{array}{c}\mathrm{RC} \\
\text { Drilling } \\
\text { (2002) }\end{array}$ & $\begin{array}{c}\text { Spacing } \\
\text { of RC holes }\end{array}$ & $\begin{array}{l}\text { Mapping } \\
\text { Windows }\end{array}$ & $\begin{array}{c}\text { No. } \\
\text { of } \\
\text { Piezos }\end{array}$ \\
\hline Name & No. & $\begin{array}{c}\text { Un- } \\
\text { oriented }\end{array}$ & Oriented & $\mathrm{m}$ & No. & $\mathrm{m}$ & No. & No. \\
\hline $\begin{array}{l}\text { Pepe- } \\
\text { Mantraim }\end{array}$ & 766 & 12 & 6 & 100 & 5510 & $25 \times 25$ & 43 & 33 \\
\hline Teberebie & 592 & 3 & 11 & 100 & 2341 & $25 \times 25$ & 37 & 9 \\
\hline Kottraverchy & 376 & 8 & 23 & 100 & 221 & $12.5 \times 12.5$ & 18 & 0 \\
\hline $\begin{array}{l}\text { Akontansi } \\
\text { Central/Ridge }\end{array}$ & 916 & 31 & 5 & 100 & 3020 & $12.5 \times 25$ & 28 & 11 \\
\hline $\begin{array}{l}\text { Akontansi } \\
\text { East } \\
\text { (Midlap-- } \\
\text { Underlap) }\end{array}$ & 230 & 2 & 0 & 100 & 5603 & $12.5 \times 25$ & 26 & 13 \\
\hline
\end{tabular}

The lithologies of percussion drilled chips are determined for each composite meter from the colour, grain size distribution, proportions and sizes of vein quartz and Birimian quartz pebble fragments. Intrusive rocks, or weathering products from intrusives are identified as either mafic or felsic. Four thick bedding-parallel, completely weathered, felsic sills were encountered; the lowermost being only about ten metres below the original (2002) Underlap pit footwall-slope. Shear zones, fault zones and mylonite zones are also logged, if detected. Once grade assays have been completed the resource geologists confirm the stratigraphy, capture the data in a database, and interpret the geology on drill cross-sections. Figure 9 shows an example structural geologic section. These sections are then interpreted in 3-D and linked to construct 3-D wire-frames, or digital terrain models (DTM's), of strata and major structures. Most faults have to be 'inferred' from abrupt displacements in strata, and can be classed as 'indicated' if actually confirmed in chips from one or more 
holes. Sills and dykes are more readily modelled directly from chips and can often be classed in the 'measured' reliability category. Major structures which turn out to adversely located and oriented relative to pit slopes are generally further explored by means of infill RC-drilling, or dedicated diamond core drilling and also mapping of interim faces.

Bedding and joint sets were also determined from scan-line and 'window' or 'cell' mapping of interim pit faces. This data was stereographically analysed and also correlated with geology interpreted from the RC and un-oriented core drilling as double-check of structural models. These rock fabric analyses explained some of the small-scale slope failures that were already occurring in the upper first-phase (Midlap) pit, and also showed that similar planar and edge failure mechanisms would prevail if the initial designs were pursued. The stereoplot in Figure 9 produced from rock mass fabric mapping shows an unfavourable intersection between batters of a sector of the East wall of the first cut Midlap pit and local bedding planes (set $2 \mathrm{~m}$ ).

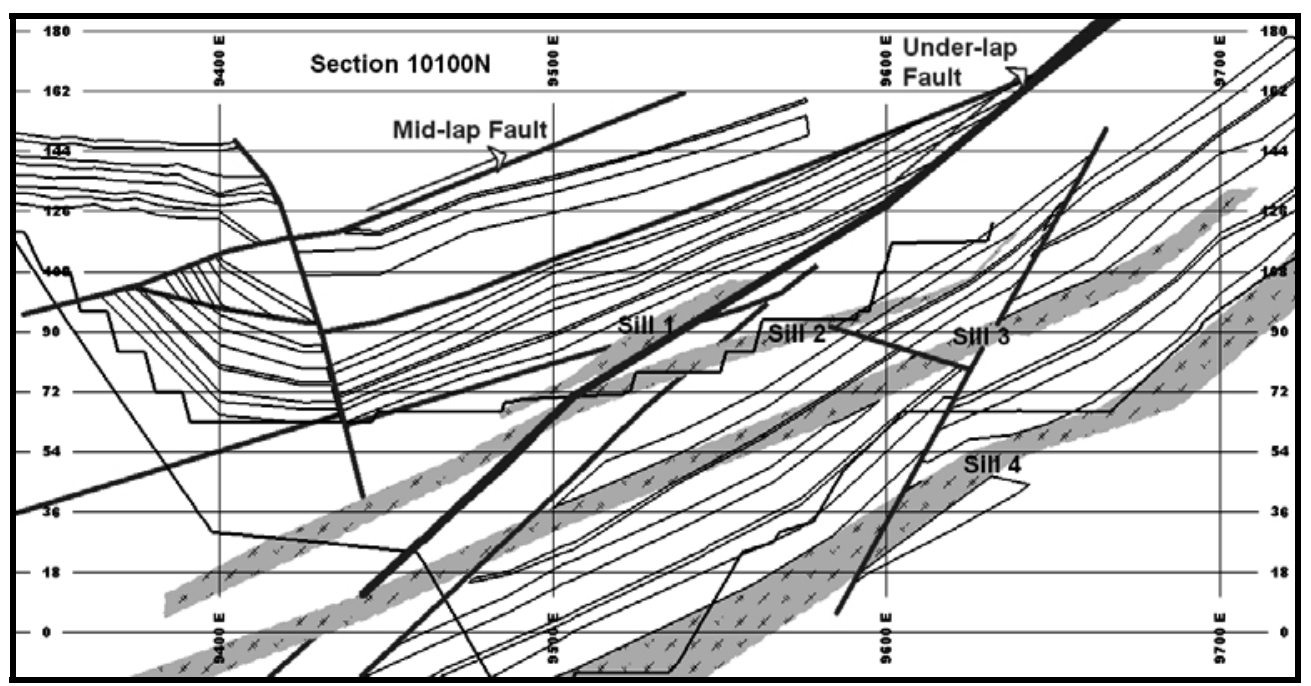

Figure 8 Example structural section showing folded and faulted strata, faults and sills

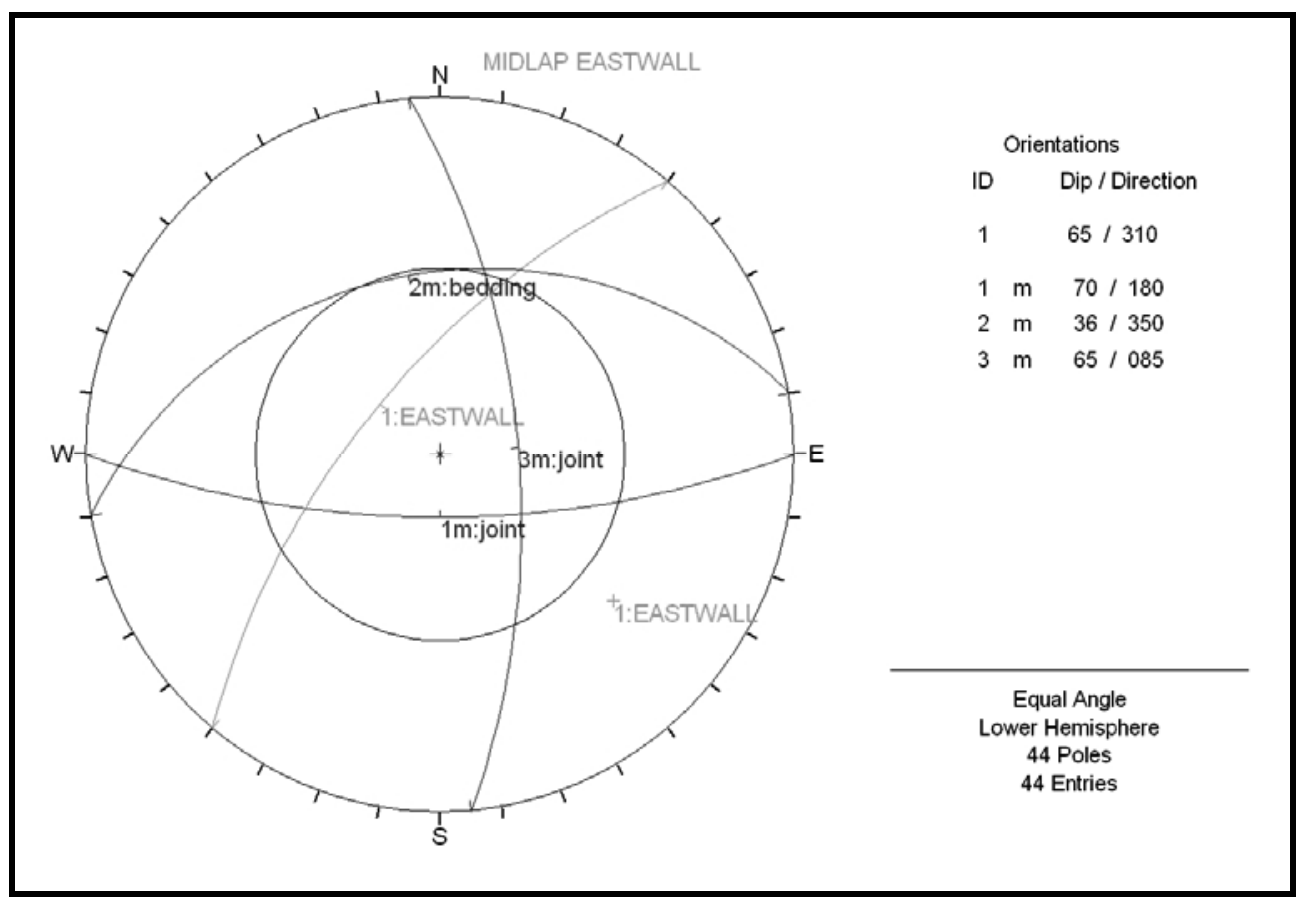

Figure 9 Stereo plot of the Midlap east slope showing plane plots 
Figure 10 shows an example of adverse orientation of bedding planes in the western limb of the Midlap syncline relative to the upper slope of a first revision of the Midlap and Underlap phase 2 pit design. The friction angle on these bedding planes was estimated at $40 \pm 5^{\circ}$, using the Barton and Chaubey empirical method, as well as back-analysis of small-scale failures. However, bedding-faults often reduce this to $30 \pm 5^{\circ}$.

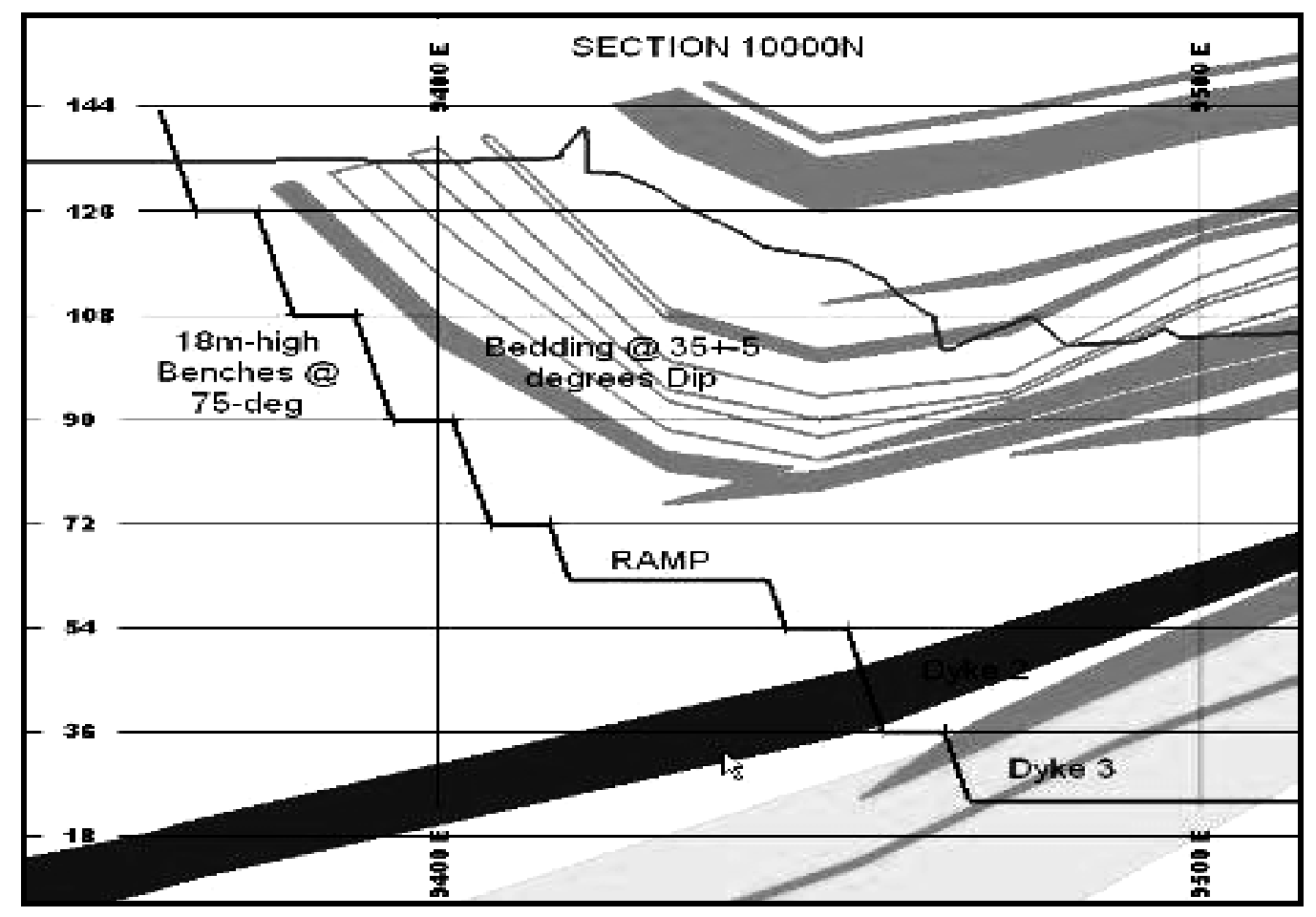

Figure 10 Example cross section where batters would undercut bedding by as much as $40^{\circ}$

\subsection{Improved pit designs and mining strategies}

The principal control over stability of the east (footwall) slope was determined to be the stratigraphically lowermost of the four sills (named sill 4). This sill is weathered to soft yellow clay with very low shear strength. Frictional angles (Ø) are typically $25 \pm 5^{\circ}$ whilst cohesions vary from 31 to $70 \mathrm{kPa}$ (Haines, 2002). Failure of the overlying slope would be certain if this dyke was undercut, with catastrophic consequences due to the sole access ramp being planned on the footwall slope. This major structure exhibits somewhat variable geometry and the upgraded structural geological model shows it also to be displaced locally by eastwest trending faults. Its general dip angle is $35 \pm 5^{\circ}$, conforming closely to that of the strata in this slope and to the lowermost gold reef. For these reasons the east (footwall) slope, which is common to all future mining phases, was completely redesigned to mine out sill 4 from the pit crest to the ultimate pit bottom. The total ramp system was relocated to the west slope. The footwall slope was reconfigured to $36 \mathrm{~m}$ high doublebenches at $35^{\circ}$ batter angles, separated with $6 \mathrm{~m}$-wide berms. No ramps were planned on the footwall and the overall slope angle was limited to $33^{\circ}$ (measured crest-to-crest to be independent of height). The bedding planes are often faulted and of low shear strength, and thrust faults in places also displace the reefs and undercut bedding. Mining footwall slopes at angles between 25 and $65^{\circ}$ pose very difficult blasting, if the underlying strata are not to be damaged. Accurate control over drill depths are exercised to minimise blast damage and ensure that batters are always mined accurately parallel to bedding.

The principal controls over stability of the west (hanging wall) slope proved more complex, variable and uncertain to overcome in design. Bedding in the west limb of a shallow syncline dictates sectors of the upper slope; deeper down the bedding is more favourably oriented, but faults are likely to impact on the slope, and thirdly: the ramp system unavoidably has to cross the weathered sills in several places. For these reasons the west slope configurations are varied across design sectors, the ramps are planned wider where projected to cross the sills, and most importantly: redundancy is provided in the design by means of alternative ramps. This facilitates some strategic flexibility in the mine plan, should adverse major structures dictate changes. 
The mining plan is divided into four phases that correspond to key decision points based on the structural geological model. Phase two is served by dual ramps, one in the south and one in the north. From phase three, access can be switched completely from the south to the north, or vice versa, depending on encountered structural geology and on slope performance. Figure 11 shows the Midlap and Underlap phase 2 and phase 3 option 1, with phase 4 routing to the south if the southern ramp systems remain stable (serviceable). Intersection with the adjacent Akontansi pit (to the bottom of Figure 11) which will ultimately mine out ramp 2 is not shown. Figure 12 shows the phase 2 and phase 3 option 2, routing Phases 3 and 4 to the north if the southern ramp systems become unstable or serviceable. The intersection with the Akontansi pits that will mine out ramp 2 is shown. Ramp 4 is planned to then join up with a ramp system on the Akontasi pit north slope. (North is to the left in both figures).

Ore reserves in phase 4 are currently classed as 'probable' due to the relatively high level of uncertainty remaining in the structural geology and pit design. The reserves classes might be upgraded in future, commensurate with improvements in models and design reliability.

Direct comparison of pre- and post-redesign reserves are not meaningful as the additional drilling also increased the resources. The reliability of reserves, i.e. the likelihood of actually recovering the contained reserves, has however been improved substantially. If the original design was followed and the footwall ramp-slope failed, as slope performance and analyses unequivocally showed it would, Tarkwa Mine would have incurred substantial loss of reserves. The flow-on impacts, like disrupted production schedules and offspec ROM ore blends to the mill, would further have compounded revenue losses and could significantly reduce the total project value.

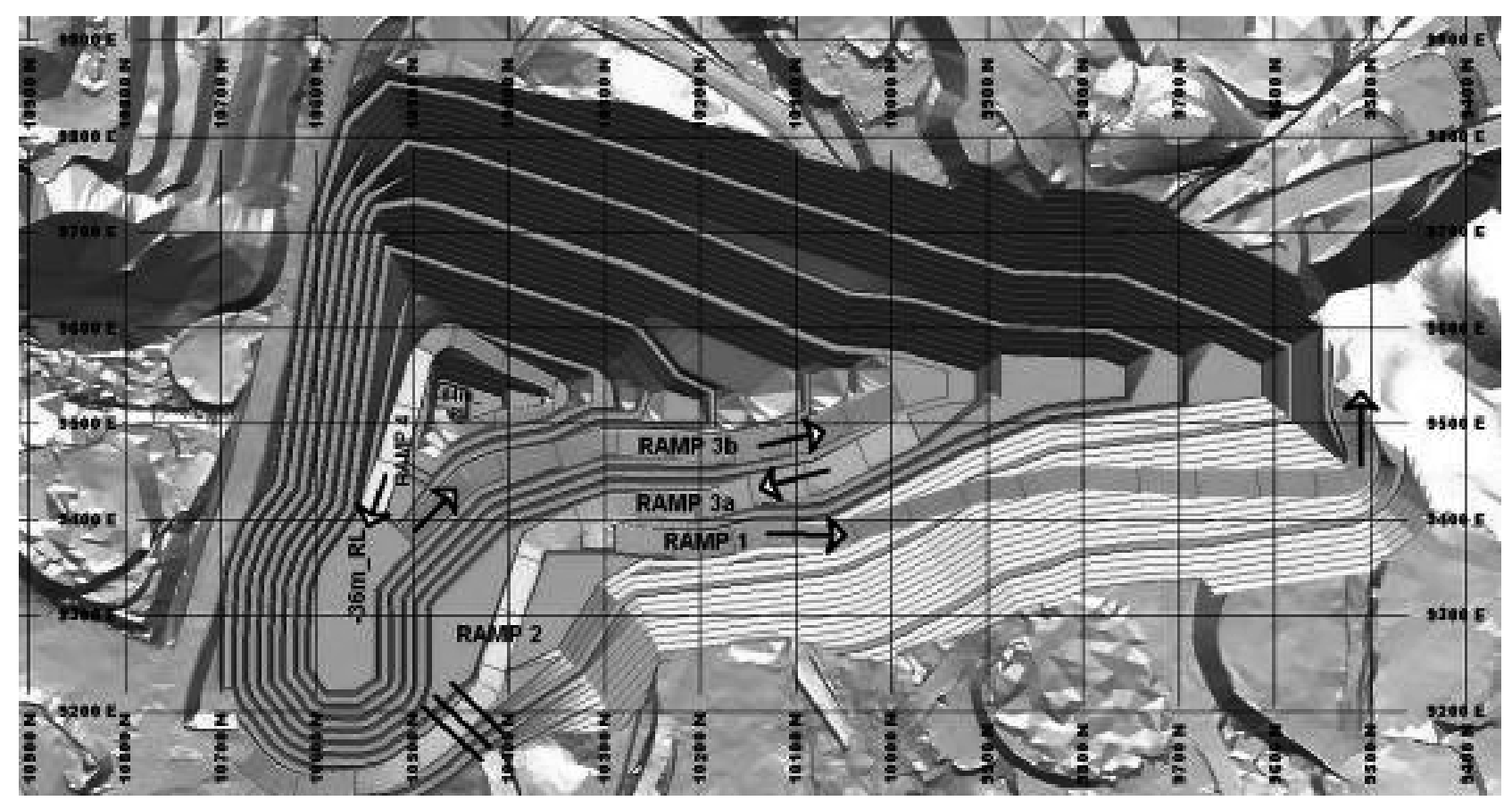

Figure 11 Design option 1 with ramps routing to the south, if the west slope remains stable 


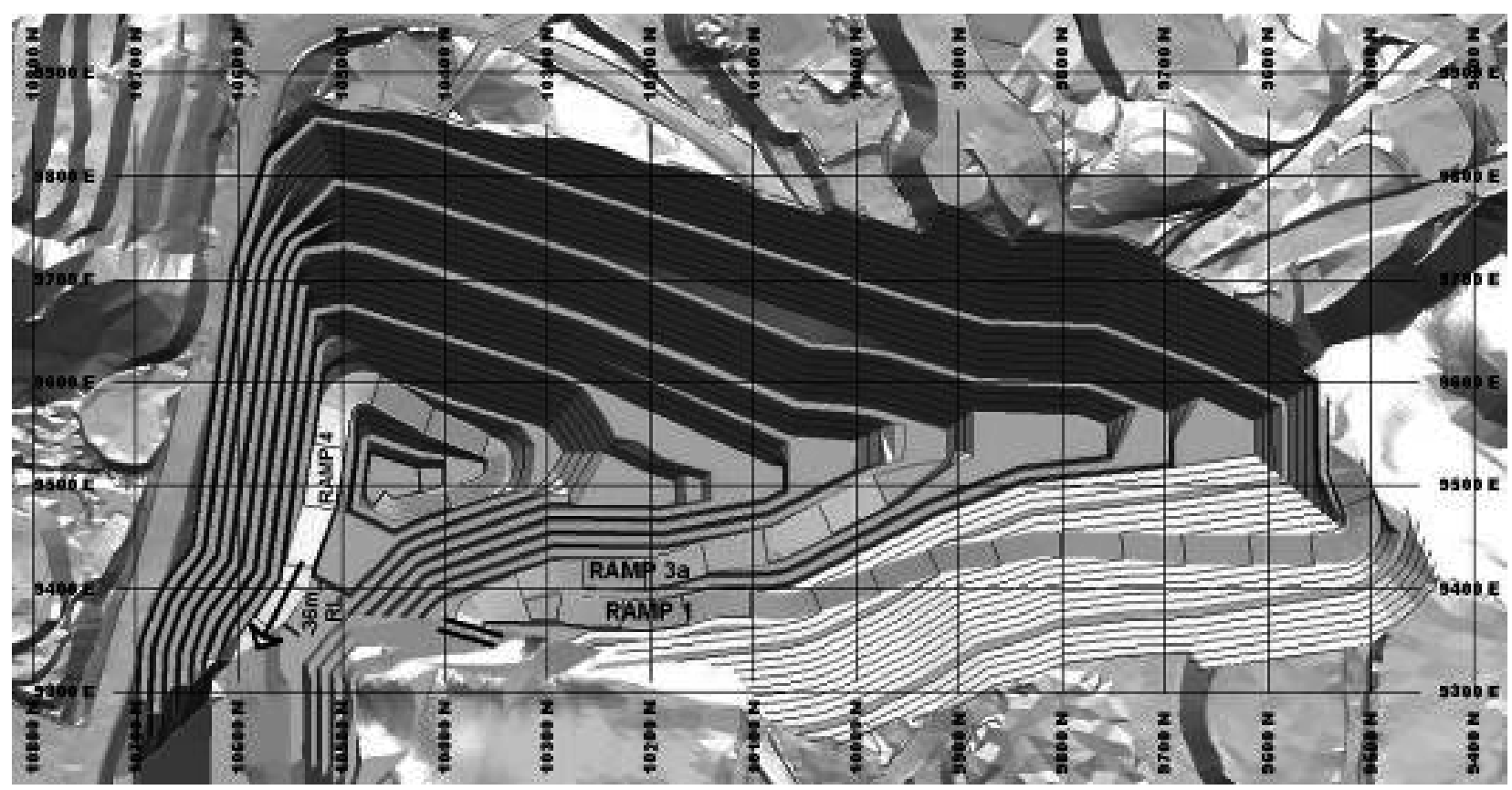

Figure 12 Design option 2 with ramps routing to the north, if the west slope becomes unstable

\section{Conclusions}

Many of the major geological structures that necessitated pit redesigns at Tarkwa mine would probably not have been overlooked if the tectonic history and structural setting of the mining area were researched from outset of geotechnical studies. Much of this information was readily available in exploration reports and published literature. In retrospect the initial geotechnical design focus at Tarkwa mine was too mechanistic and relied too heavily on empirical methods for estimating slope angles and as inputs for numerical models. Slopes of good to very good quality rock masses simply failed, or would have failed if constructed on single adverse major structures. Currently slope designs are based on dedicated exploration for understanding and detailed 3-D modelling of bedding, folding, faults and dykes. Structural geologic models are extended into the footwalls below ore reefs and beyond ultimate pit limits. The structural expertise of resource and mine geologists is fully utilised to assist with geotechnical pit designs. This structural geological emphasis has significantly improved the reliability of slope designs, mine plans, ore reserves and the safety of operating the Tarkwa Gold mine. Reserve classifications account for the grade of reliability of geotechnical models and resulting pit designs.

\section{References}

Grififis, R.J., Barning, K., Agezo, F.L. and Akosa, F.K. (2002) Gold Deposits of Ghana, published by the Ghana Minerals Commission.

Haines, A. (2002) Review of slope stability and associated mining geotechnical conditions at the Tarkwa Open Pit Operation, Ghana, SRK Consulting report.

Karpeta, W.P. (2000) A review of the geology, mining and exploration of the Tarkwa Mine area. Harwood International report.

Karpeta, W.P. (2001) The structural evolution of the Tarkwa basin in the Tarkwa mine area. Bastillion Limited report.

Saayman, A.F. (2005) 1st iteration Midlap \& Underlap pit geotechnical redesign. Geotec-Africa report. 